\title{
The Afghan Refugee in Pakistan: An Ambiguous Identity*
}

\author{
PIERRE CENTLIVRES AND MICHELINE CENTLIVRES-DEMONT \\ Institute of Ethnologv, University of Neuchâte/; \\ Neuchâtel, Switzerland
}

\begin{abstract}
Since the Afghan crisis and the Soviet intervention of December 1979, more than three million Afghans have sought refuge in Pakistan. During fieldwork (1986-87), we tried to find out how the exile situation has affected their identity.

The Afghan refugees seem to define themselves along three ideological models. The most familiar to us is the one of 'refugee' as defined and governed by the Convention of the United Nations of 1951. The second is related to the norms of the tribal code of honour as practised by the Afghans, where tribal groups seek temporary shelter among kin. The third model, that of mohajer, and perhaps the most important, refers to Muhammad's flight from Mecca to Medina in $622 \mathrm{AD}$ and has a religious significance. The second and the third models are more significant than the first.

To the outsider, each of the three types of identity may seem to contradict the others. To the Afghan refugees, however, these diverse constituents of a new and complex identity are not contradictory; instead, they coexist in the consciousness the refugees have of their situation and are used in different ways, according to the context.
\end{abstract}

Quand des habitudes séculaires s'effondrent, quand des genres de vie disparaissent, quand de vieilles solidarités s'effritent, il est, certes, fréquent qu'une crise d'identité se produise (Claude LéviStrauss, L'identité, p. 9).

Since the Marxist Coup on 27 April 1978 and the Soviet intervention in Afghanistan on 27 December 1979, more than three million Afghans have sought asylum in Pakistan. This exodus has several causes, but is due in particular to military operations and repression in Afghanistan, as well as to the refusal of the Afghan people to submit to a government they consider atheist.

The above quotation of Lévi-Strauss applies perfectly to the situation of the Afghan refugees in Pakistan. For these Afghans, what was once the basis of social life, power, and daily existence has been threatened if not completely disrupted or even destroyed. As the Pakistani anthropologist Akbar Ahmed, member of the Civil Service, put it: 'The kaleidoscope of traditional patterns (C) Oxford University Press 1988

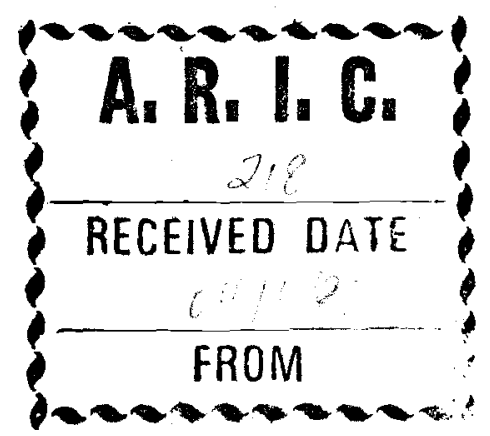


has been shaken - leadership, women, and even children are affected. New voices are being heard, new values emerging. Afghan society will never be the same again' (1986:166).

It is important to realize that the livelihood of 85 per cent of the Afghan population depended on agriculture at the time of the Coup of 1978 (Centlivres 1985), while now, in Pakistan, the Afghan refugees (AR) have no access to the land. Consequently, the relations of production - in other words the very foundations of social hierarchy, power and influence, alliance and inheritance which are bound to the possession of the land - are being challenged in the new situation. Out of this upheaval affecting the lives of millions of people, what are the cultural resources the refugees can count on to help them reorganize their existence, their social relationships, and their mental universe? On which beliefs can they base their ideas of what is happening to them? From what can they reconstruct an identity?

The image of Self and Other, or social identity in Afghanistan, rested not on an idea of nation and citizenship, but on a feeling of appurtenance both to a supranational entity, the Islamic community or umma, and to an infranational one, the regional, tribal, or ethnic community (Centlivres 1980; Centlivres and Centlivres-Demont 1981-82). However, though the AR continue more than ever to claim that they belong to the Islamic faith, the Islamic community itself appears divided, since the government in Kabul also claims to be orthodox Islamic. As for the bases for an infranational identity, they are completely shaken by exile itself, since the AR, transplanted from their environment, no longer live in their former communities composed of kinship or neighbouring groups.

In these conditions, the identity of Afghans exiled in Pakistan cannot help but mirror the crisis and its complexity, contradictions, and transformations. Yet within this disrupted society an observer can discern certain conscious models which organize perception and practices. Images or general schemes which have been borrowed and enculturated contribute to ideological construction and to the quest for identity.

In the following text, we examine the new dimensions of the identity of the Afghan refugees by exploring the notion of 'refugee' as it is lived and imagined by the AR themselves and by all those who have to deal with them.

\section{Fieldwork among Afghan Refugees}

We worked as a couple in Afghanistan several times between 1964 and 1978, a total stay of more than four years. Our research centred first on the markets in particular that of Tâshqurghân, between Mazar-i Sharif and Kunduz (Centlivres 1972), then on questions of ethnic identity and interethnic relations in North Afghanistan. After the Coup of 1978 and Soviet intervention in 1979, fieldwork was no longer possible within Afghanistan. In 1986 we applied for a grant from the Swiss Directorate of Development Cooperation and Humanitarian Aid (DCA) to study the material and symbolic forms of adjustment of the AR in Pakistan. 
We worked particularly in Chitral, in the Peshawar district, where there is the greatest concentration of refugees in Pakistan; in Waziristan; in Baluchistan; and in Mianwali in the province of Punjab. Here the Pakistani administration has set up new camps to avoid overpopulating the North West Frontier Province (NWFP) and to keep AR away from the Afghan border. Our stay in the camps was facilitated by the Pakistani authorities and the UNHCR. Our knowledge of dari (Afghan Persian) permitted us to converse directly with the AR, including the Pushtuns, who almost all know the second language of Afghanistan.

Refugees from different origins, in particular former notables - 'white beards' - and representatives of the political parties of the Afghan Resistance, as well as employees of the Pakistani camp administration and experts from International Organizations were interviewed. We also had the opportunity to speak with teachers from both the official and the religious schools for Afghan children, and with Pakistanis who live near the refugee camps. To complete the data we consulted documents pertaining to the Pakistani administration of the camps and a corpus of brochures, magazines, and bulletins edited by different movements of the Afghan Resistance.

During our fieldwork in Pakistan in the Autumn and Winter of 1986-87, we tried to find out, among other things, whether the notion of 'refugee', for those concerned, was identical to that of the Convention of the United Nations of 1951 and the ensuing Protocols, and - in the likely case that there existed a gap between the Afghan concept and that of the UNHCR - to discover the ideological model which the AR referred to in order to define themselves.

Broadly speaking, our work helps to point out the ambiguity of the concept 'refugee', and the difficulty that one encounters when the definitions drawn up by international law are confronted with culturally different conceptions within a concrete situation.

\section{Three Facets of Identity}

For the International Organizations (IO) and the Government of Pakistan (GOP), the refugees are defined and governed by the Convention of the United Nations of 1951 which was expanded by the ensuing Protocol of 1967 and, for Africa, by the Convention of the Organization of African Unity of 1969. According to the Convention of 1951 and the Protocol of 1967, the refugee is a person who, 'owing to well-founded fear of being persecuted for reasons of race, religion, nationality, membership of a particular social group or political opinion, is outside the country of his nationality and is unable or, owing to such fear, is unwilling to avail himself of the protection of that country ... (Article 1A).

According to the abundant literature dedicated to refugees, one notices first of all that priority is given to the individual: the 'refugee'. The latter is described as being a victim of circumstances over which he has no control, condemned to poverty and dependence, and having a right to humanitarian relief; he must be given refuge, protected, nourished, and cared for - in other words taken 


\section{Pierre Centlivres and Micheline Centlivres-Demont}

charge of (see Hyndman 1987 and Refugees: Dynamics of Displacement 1986, among others). As D'Souza points out, the stereotype of the refugee includes the following characteristics: 'poor, ill-educated, and undernourished. The common view (often derived from media pictures or charities' advertisements) is one of pathetic individuals, their children and a few belongings on their backs, fleeing with fear and bewilderment in their eyes' (1981:7). These images are also reflected in the pathetic genre of a publication of the Ministry of Information and Broadcasting, Islamabad: 'Old and infirm, maimed and mutilated, male and female, with sucking babies, tiny toddlers and infants, three million of them!' ('Afghan Refugees in Pakistan':3).

It is true that the image is not inappropriate for describing the misery which is the lot of so many AR. Upon arrival, the AR are taken charge of by the UNHCR, the Government of Pakistan and the NGOs (Non Governmental Organizations) which offer supplies, care, and shelter with great efficiency. Afterwards these organizations must face other, more long-term problems such as education, the promotion of self-reliance and income generating activities, and finding the means for their wards to return home or to be accepted by a third country. In appealing to the UNHCR in April 1979 when faced with a burden of refugees it could not assume alone, Pakistan put the AR under the protection of the IOs and thus caused them to be caught up in a complex system of customs and meanings which were foreign to them.

However, as Akbar Ahmed points out very clearly, the AR in Pakistan are for the most part Afghan Pushtuns who have sought asylum in a Pathan (Anglo-Indian name for Pakistani Pushtuns) territory in Pakistan, inhabited by a population with whom they share the same language, the same culture, and the same value system (1986: chap. 10). Rather than victims, accepted according to humanitarian law, one could perceive them - at least in the beginning of that enormous migration - as beneficiaries of traditional hospitality of fered by the Pakistanis of the NWFP to their brothers from the other side of the border. Indeed, it was not just any hospitality, but one dictated by the strict norms of the pushtunwali code of honour as practised by the Pushtuns.

From this viewpoint, the image that these 'refugees' offer of themselves is not one of a mass of unarmed and helpless individuals, but one of organized groups seeking temporary shelter among kin. We can again quote Ahmed: 'On crossing into Pakistan, Afghans were received as fellow Muslims and, equally important, fellow tribesmen' (1986:166). Thus we are far from the image of the miserable masses of hopeless refugees regrouped in camps, as one pictures them at times based on the image of the victims of other catastrophes. Instead we have Afghan tribal groups which were received by the tribal Pushtuns of Pakistan.

In fact, the Pakistani population sometimes wonder if they are not facing a new type of invasion instead of a flow of victims of war. Ahmed also remarks that "their bearing adds to their historical image of themselves as conquering warriors. They are quite unlike the refugees who came to Pakistan from India in 1947, and the Biharis from Bangladesh in 1971' (1986:165). 
A third important field of meaning is evoked by the term mohajer/mohajerin, an Arab term which is translated as 'refugee(s)' in all Islamic countries. Mohajer has the same root as hejra, or Hejira, which refers to Muhammad's flight from Mecca to Medina. The verb which is used in Persian, and in particular for all the refugees with whom we spoke, hejrat kardan, means 'to go into exile', especially for religious reasons, when the regime in power does not allow the free practice of Islam. A mohajer is one who voluntarily goes into exile, and who has severed the ties with his own people and his possessions to take refuge in a land of Islam. Thus we have a term (and a model of behaviour) which dates back precisely to the year of the foundation of the Islamic era, 622 $\mathrm{AD}$, and thus has very deep religious connotations. The historico-religious notion of mohajer is the object of strong identification on the part of the AR.

According to this conception, the inhabitants of the host country are associated with the merit of the mohajer; they are ansar, or auxiliaries, according to the name given to those who, in Medina, welcomed and aided the exiled from Mecca. For the Prophet, these two categories of believers, the mohajer and the ansar, 'should enjoy rights of kinship with one another' (Gibb and Kramers 1961:390). The title of ansar is used in Peshawar by the leaders of Afghan Islamist movements in their orations, when they greet the Pakistanis present in their midst. During these speeches they respect the hierarchical order according to religious merit: mujahed (fighter in the jehad, or Holy War), mohajer, and ansar.

One might presume that the AR adhere to one or another of these three sets of meanings. It seems more accurate to us, however, to say that these three notions coexist in the consciousness the AR have of their situation, but that they are used in different ways, according to the context. They are used in interactions with the representatives of the IOs, GOP delegates, nationals of Arab countries, or Pakistani neighbours. However, the possibility of using any of the three notions at will - mohajer, temporary guest of a related tribe, or refugee according to the international meaning of the term - will weaken with time. The AR are not in full control of their own situation.

\section{Ideological and Practical Potential}

Using the three types of identity, we can try to evaluate the ideological and tactical potential of each. Without being exactly what Max Weber termed 'ideal types', they do act as sets of values and meanings, and contribute to the construction of identity.

The condition or the status of mohajer is very significant - the term is used in Friday's sermon by the imam - since one is mohajer according to the model of the Prophet's companions, who left Mecca for an honourable reason: 'But the believers, and those who emigrate and struggle in God's way - those have hope of God's compassion; and God is All-forgiving, All-compassionate' (Arberry: Koran, Sûra II, 215). 'And those who emigrated, and were expelled from their habitations, those who suffered hurt in My way, and fought, and 
were slain - them I shall surely acquit of their evil deeds, and I shall admit them to gardens underneath which rivers flow' (Sûra III, 195). As Gibb and Kramers state, 'Muhâdjir in this way became a title of honour', and 'With the greatest eloquence, Muhammad describes them as the particular favourites of Allah: who will receive a splendid reward for their sacrifices' (1961:390).

The mohajer is thus not at all a shameful fugitive but, on the contrary, someone who has made a sacrifice for his faith through leaving the comfort of the family, and perhaps even the favours of the government in power. At the beginning of the events in Afghanistan, several village communities left together, under the leadership of their mullah or other religious leaders. Men adopted or reinforced the physical appearance which is prescribed by Islamic custom: beards and turbans (or other headgear without visor) are worn; former middle-class educated men abandoned what resembles Western clothing, in particular the tie or straight trousers. It is also clear that the term mohajer only partially covers the concept of refugee as we mean it, since (still with reference to the model of the Prophet's companions in Mecca) being mohajer does not at all imply giving up the struggle. Instead it implies a momentary tactical retreat preceding return and reconquest. Mohajer is thus the other side of mujahed (fighter in the Holy War), and the two are associated with each other in the Koran; the passages which refer to them are constantly cited in the periodicals of the Resistance movements: 'Those who believe and have emigrated, and have struggled in the way of God with their possessions and their selves are mightier in rank with God; and those - they are the triumphant' (Sûra IX, 20).

This association between mohajer and mujahed is fully assumed by many of the AR who call themselves mujahed when they are on the point of leaving to fight in Afghanistan, and mohajer when they are just arriving in Pakistan. Thus, in the logic of the fighters for Islam, there is a 'two-fold' person, the mohajer/mujahed, which of course complicates the situation and overturns certain preconceptions held by the international officials of the UNHCR.

But the duality mohajer/mujahed is considered with irony' and reproach by the Pakistani opposition press, which see the AR as 'false refugees', dangerous foreigners who bring risk and insecurity to Pakistan itself. As Akbar Ahmed states, 'they are a swaggering, armed, aggressive lot' (1986:165).

With time, however, the significance of mohajer could well be questioned. From the time that exile in Pakistan is no longer considered as a phase in the fight for the faith, and if, instead, the AR settle in Pakistan or emigrate to another country definitely, there is a risk that they will fall into the category of 'refugee' as it is meant by humanitarian organizations. Or, mohajer could come merely to signify a category of persons, a sort of ethnic term. This was the case of the Uzbeks and Kazakhs from Soviet Central Asia who spoke a Turkish language and fled the Soviet regime in the 1920s and 1930s for religious reasons, and then settled in the north of Afghanistan with no hope of returning (Shalinsky 1979). This is also what Muslims who settled in Pakistan after the Partition (1947) and the secession of Bangladesh (1971) are called. In 
the latter case, mohajer no longer designates someone who sacrificed homeland or possessions, nor a fighter in reprieve; it is simply a category of persons distinguished from the native population.

For tactical reasons, the Islamic image of mohajer is pushed to the forefront for representatives of other Muslim countries when Islamic fraternity is in question. It is also a powerful and significant motivational force in the construction of identity. From a personal point of view, it renders a refugee almost a fighter and, from a collective point of view, it binds the group to the very sources of Islam.

As Edwards points out, the notion of hospitality, melmastia, as well as those of refuge, nanawatia/nanawati, or asylum, panah, are associated with Pushtun identity. He adds that 'migration and movement emerge as part of the Pakhtun mythology just as cross-border movements in response to political pressures from neighbouring governments continue to be thought of as necessary actions taken to preserve cultural values which might otherwise be jeopardized' (1986:317). Melmastia, nanawatia and panah are part of the pushtunwali.

According to this code, taking a person in who is in difficulty involves rights and obligations for both parties, and implies that the host take sides with his protégé in a quarrel (see for instance the Pakistani diplomacy in the Geneva Talks). Of course it also supposes total protection of the guest, even at the host's expense. At the beginning of the exodus in the early 1980s, khans (Pathan tribal leaders) of the NWFP in Pakistan, as well as the descendants of mehtars (sovereigns) from Chitral, settled the AR on their own lands, which conferred certain advantages on the latter, but also implied the duties which result from hospitality. Of course in this case, the Afghan refugees stood up for their hosts in quarrels the latter had with their neighbours. For the AR, the host 'par excellence' is General Zia, the present ruler of Pakistan, and consistent with the duties hospitality implies, several Afghan leaders have affirmed that they would fight for Zia-ul-Haq in case of any conflict with India. This type of hospitality and reciprocal obligations has been studied by Lindholm (1982), in the context of another Pushtun population, the Yusufzai of Swat. He showed how weaker clans which had conflicts with the government or with powerful enemies would take refuge with their neighbours, who in turn had the possibility of recruiting armed troops from among their 'guests' to carry out their own objectives. 'The principle of refuge was formerly applied in Swat to recruit armies from the ranks of fugitives seeking asylum', according to Lindholm. 'Refuge, like hospitality, has its instrumental side - but refuge must be offered even if it is politically ruinous and [. . .] the host can be forced into fights he does not want by the demands of nanawatia' (Lindholm 1982:235).

In principle, the relations between guest and host do not necessarily imply inferiority and dependence on the part of the former party, but it is clear that if the situation continues, the honourable position which existed in the beginning tends to become strained, and relations become asymmetric; a clientele relationship can even develop. 
As Edwards also adds, 'while the institution of asylum (panah) exists in Pakhtun society and is recognized as an honorable and necessary option which individuals and groups must take to preserve both their own lives and the integrity of the tribe, the individual who is granted asylum takes on an ambivalent status which may ultimately result in his having to accept a subordinate position to his sponsor and his sponsor's tribe' (1986:318). One cannot eternally be someone's guest without becoming dependent. In general this hospitality is conceivable only if it is potentially reciprocal, and if after a certain lapse of time those who benefit from it return home and can, in turn, offer hospitality themselves.

Another dissonant note concerning the situation of hospitality is the sheer numbers which have crowded into Pakistan, and which have greatly surpassed the capacitites of the tribes and tribal chiefs on the Pakistani side for receiving them. One has to keep in mind, also, that many of the refugees in recent years are not even Pushtun, but belong to other populations from Afghanistan, for example Persian-speaking Tajiks and Turkish-speaking Uzbeks and Turkmens, among others. Since they do not live according to the pushtun wali code, one can understand that the notion of hospitality or asylum can no longer characterize the whole Afghan refugee situation, nor can it furnish a satisfactory basis for identity.

However, the melmastia and the nanawatia have certainly permitted the management of a significant part of the relationships which exist between Afghan and Pakistani tribal groups in the tribal zones. In fact, it is through tribal relations that the diplomacy of Kabul has been trying to create scissions and win over adherents.

\section{The Use of Identity: Perspectives and Limits}

In returning again to the first term, 'refugee', we discover a condition determined first and foremost by international conventions and then implemented, quite efficiently, through a bureaucratic organization, the High Commissionerate for Afghan Refugees of Pakistan. In this situation the IOs and the host country impose very strict conditions which conform to international conventions and to the ideology of IOs: demographic surveys, population censuses of the camps, the distribution of documents which certify the status of 'refugee', and imposed individualization through aid, according to the individualist and democratic creed of the UNHCR.

This aid, though welcome and generally well organized, goes against traditional forms of distribution which are collective and hierarchical in nature. In the camps when food is distributed these imbalances become evident; dependence is obvious, as the lines of AR form to receive their food: Pakistani guards and functionaries hold registers in which the recipients sign with a thumbprint, concretely revealing the refugees' reality against a backdrop of corrugated iron silos and fuel stocks, surrounded by barbed wire.

The term 'refugee' reflects a position imposed from the outside, in a foreign ideological context, a position which supposes dependence and which 
contradicts - partially at least - the ideas of mohajer and melmastiananawatia. This situation of dependence is disparaged even more because it implies the abandonment of a tribal code of honour, of a part of the Islamic religious ethic and, at least in part, of ties with the qawm (lineage or regional group). This is why, in the Afghan refugee villages, the AR try to recreate something of their autonomy, either through the role they accord their former or new 'tribal' notables, or through the structures set up by the political parties of the Resistance (Centlivres and Centlivres-Demont 1987).

Circumstances have forced the AR to conform to the image of a foreignimposed identity, whereas in identifying either with the mohajer or as a neighbour's temporary guest, they call upon ideological and practical resources drawn from their own culture. In addition, the notion of 'refugee' in a context of human and international rights represents very large stakes since it is through this channel that the UNHCR, the World Food Programme, the World Bank and the Voluntary Agencies (VOLAGs) send food, medical assistance, and all other forms of aid.

The refugees, and the notion 'refugee', are also the stakes of Resistance groups - particularly of Islamist parties - who seek control of the camps and of the religious schools. On several occasions collaborators of Gulbuddin Hekmatyar, leader of the most radical Islamist party, told us that representatives of their movement were better able to organize aid distribution and to fight against corruption than agents of the IOs.

Each Resistance party has its own religious schools (primary and sometimes secondary) in the camps, called madrassa. Schoolbooks emphasize notions such as mohajer/mujahed/jehad. Aid organizations of Arab countries open hospitals and supply dispensaries and are thus sometimes in direct competition with international or Western humanitarian organizations. Thus it is not surprising to see the AR act like 'refugees', in the UNHCR sense of the term, offering the image of a good recipient of welfare - a grateful, docile victim to foreign visitors, VIPs and journalists. Certainly it is an act which, though contrary to the Afghan ethos, is considered to be necessary and profitable, but it is also a trap within which the refugees actually do become increasingly dependent.

It is not surprising either that when faced with interlocutors other than the IOs and other Western organizations, they insist on presenting themselves as Muslim and mohajer. Seen from the outside, each of these identities not only is different, but also seems incompatible with the others. In a Koranic passage known by all refugees, Muhammad and his mohajer companions act as independent agents, making new alliances, fighting battles, and finally triumphing over their enemies and reconquering Mecca. As we saw, the roles of mohajer/mujahed and refugee/fighter, are relative to time and space. In the camps the refugees take in the mujahedin returning from combat. The religious schoolmasters in the camps must carry out military service in Afghanistan during the school holidays. Certain madrassa for refugee children offer paramilitary training. 


\section{Pierre Centlivres and Micheline Centlivres-Demont}

Mohajer does not correspond to the UN definition of refugees, and the UNHCR in particular has to distinguish clearly fighters from expatriated victims. They struggle to prohibit any arms in the camps and attempt, sometimes vainly, to ensure that the aid which is given out does not end up diverted as supplies to the 'bachelor camps', in other words to the mujahedin. But the definition of 'refugee' according to the pushtunwali ethos is also not acceptable to the UNHCR, which considers the community ties - and in particular the ties of dependence with traditional notables - to be incompatible with the fair and equal distribution of aid. The UNHCR tries, with a fair amount of success, to sever former ties, to suppress the system of redistribution by malek, and to replace it with a direct system of aid to heads of families (Centlivres and Centlivres-Demont 1987).

But melma ('host' in pushtu) and mohajer are not compatible either, since the Islamist movement, which is very influential in the refugee villages, refuses any basis other than Islam for society in general, and for political institutions in particular. It absolutely takes exception - even if it admits to certain practical compromises - to anything which resembles ethnic and tribal allegiances and 'clientelism'. But for the AR, these diverse constituents of their identity are not contradictory. The situation in which they find themselves has brought them not only to accept food rations from the UNHCR, but also to define themselves as exiled for their faith and to make use of their position within the tribal structure.

\section{Implications of Long-term Exile}

Everything leads us to believe, however, that a prolonged period of exile in Pakistan will tend to favour the reality of 'refugee' in the way it is defined by the UNHCR, rendering the other two meanings less credible and less operative. From a certain point of view, this new and complex identity constitutes a different kind of anchorage from the former feelings of ethnic or regional appurtenance; different, too, from the sentiment of belonging to Islam which is simply an attachment to its cultural character and traditional practices. This deepened commitment to Islam, considered as an ideology, permits the emergence of a renewed concept of State and power (Roy 1985:107) and is precisely that which makes a good number of refugees adhere to the Islamist parties of the Afghan Resistance to the detriment of former ethnic or tribal solidarities.

The Afghans are not the only ones to have found a new identity by redefining themselves in relation to the situation of exile: the host country, or at least certain of its inhabitants or leaders, also define themselves in relation to the refugees. As ansar, or auxiliaries, neighbours, and poor but gracious hosts, weighed down by the overwhelming burden of three million refugees but brothers in Islam and hospitable cousins, the inhabitants of Pakistan and its Government thus deserve the sympathy of the 'free world', and the support of Islamic countries. By of fering asylum, are they not increasing their 'symbolic capital', and their economic opportunities as well? This is what political 
commentators say, with some cynicism, when they point out that with the arrival of the Afghans, the authoritarian government of General Zia acquired a new honourability and considerable foreign aid.

So, part of the Pakistani population takes exception to the reassuring image of the guest/host relationship. For them, the AR are too numerous, have remained in the NWFP for too long, and are suspected of all sorts of trafficking. Their behaviour is far from being that of melma, a guest with the rights - and especially the duties - described by the pushtunwali.

The very presence of three million refugees as the UNHCR defines them provokes the impatience of the Pakistanis. In the opinion of many of them, the free aid and the camp infrastructures available to the AR permit the refugees to accept salaries lower than those demanded by Pakistani workers, thus enabling the refugees to compete more favourably for local employment. In addition, the mohajer is perceived, as we have seen, as a 'false' refugee who does not conform to a dependent role and threatens the security of Pakistan by guerrilla activities carried out against a neighbour.

In demanding that the AR be sent back to their country, many Pakistanis do not - or no longer - see themselves in the role of ansar, no more than they see themselves as tribal hosts. Nor would they be prepared to recognize the exiled Afghans in their country as refugees in the terms of the Convention of 1951.

If the Afghan problem cannot be resolved soon, it may well be that Pakistan - under pressure from its neighbours and the opposition within the country will reinforce its borders with Afghanistan and confine the AR to the camps. In these conditions, a long-term exile in Pakistan would render the AR even more dependent on IOs and the UNHCR, which would mean the two other forms of identity would become less credible for the AR's interlocutors and less salient for themselves.

Thus, one can better understand the determination of the Afghan communities to keep a certain degree of autonomy in relation to the Pakistani camp administration, for example by maintaining committees headed by leaders or representatives of the Resistance parties (Centlivres 1987). One can also better understand their determination to keep up their hopes of returning to Afghanistan and not to relinquish any of the three components of their identity: refugee/mohajer/melma.

The philosophy and the laws of the international conventions on refugees are, for us, universal; they are derived from 'human rights'. Yet they also belong to Western history and philosophy, and in this sense they may be foreign to the cultural tradition of those to which they are applied. To impose them without considering possible differences is to risk misunderstanding and conflict; it may even threaten the raison d'être of those compelled to seek assistance.

'AFGHAN REFUGEES IN PAKISTAN' (n.d.) Islamabad, Ministry of Information and Broadcasting, 9 pp.

AHMED, A. S. (1986) Pakistan Society: Islam, Ethnicity and Leadership in South Asia, Karachi, Oxford University Press. 


\section{Pierre Centlivres and Micheline Centlivres-Demont}

ARBERRY, A. J. (1980) The Koran Interpreted, London, George Allen and Unwin.

CENTLIVRES, P. (1972) Un bazar d'Asie Centrale. Forme et organisation du hazar de Täshqurghân (Afghanistan), Wiesbaden, L. Reichert Verlag.

- - (1980) 'Identité et image de l'autre dans l'anthropologie populaire de l'Afghanistan', Revue européenne des sciences sociales et Cahiers Vilfredo Pareto (Genève) 18:53, pp. 29-41.

- -(1985) Paysannerie et pouvoir en Afghanistan: de la fin de la monarchie à l'intervention soviétique, Genève, Institut universitaire de Hautes études internationales.

- - (1987) 'Les camps de réfugiés au Pakistan. Gestion administrative et organisation politique', in Les réfugiés afghans. Dossier, [supplément de ] Les Nouvelles d'Afghanistan (Paris), novembre, pp. 18-23.

CENTLIVRES, P. and CENTLIVRES-DEMONT, M. (1981-82) 'Village en Afghanistan', Commentaire (Paris), no. 16, pp. 516-25.

- (1987) 'Sociopolitical Adjustment among Afghan Refugees in Pakistan', Migration World Magazine (New York), XV: 4, pp. 14-22.

- - (1988) 'The Afghan Refugees in Pakistan: A Nation in Exile', Current Sociology (London/Oxford), in press.

D'SOUZA, F. (1981) 'The Refugee Dilemma: International Recognition and Acceptance', Minority Rights Group (London), Report no. 43, 20 pp.

EDWARDS, D. B. (1986) 'Marginality and Migration: Cultural Dimensions of the Afghan Refugee Problem', International Migration Review XX: 2, pp. 313-25.

GIBB, H. A. R. and KRAMERS J. H. (1961) Shorter Encyclopaedia of Islam. Leyden, E. J. Brill. HYNDMAN, P. (1987) 'The 1951 Convention Definition of Refugee: An appraisal with particular reference to the case of Sri Lankan Tamil Applicants', Human Rights Quarterly 9, pp. 49-73. LÉVI-STRAUSS, C. (1977) L'identité, Paris, Bernard Grasset.

LINDHOLM, C. (1982) Generosity and Jealousy: The Swat Pukhtun of Northern Pakistan, New York, Columbia University Press.

REFUGEES. DYNAMICS OF DISPLACEMENT (1986) A Report for the Independent Commission on International Humanitarian Issues, London and New Jersey, Zed Books L.d.

ROY, O. (1985) L'Afghanistan. Islam et modernité politique. Paris, Seuil.

SHALINSKY, A. (1979) 'Central Asian emigres in Afghanistan: Problems of religious and ethnic identity', Afghanistan Council Occasional Paper 19, New York, The Asia Society.

MS received December 1987; revised MS received March 1988.

* Translated from the French by Mary Ellen Chatwin. 